Original Research Paper

\title{
Fractionation of Organic Carbon in Arial Beel Wetland Soils of Bangladesh
}

\author{
${ }^{1}$ Monera Akter Eva, ${ }^{2}$ Mahmudul Islam Piash, ${ }^{3}$ Md. Faruque Hossain and ${ }^{1}$ Zakia Parveen \\ ${ }^{1}$ Department of Soil, Water and Environment, University of Dhaka, Dhaka 1000, Bangladesh \\ ${ }^{2}$ Department of Soil and Environmental Sciences, University of Barisal, Barisal 8200, Bangladesh \\ ${ }^{3}$ American International University-Bangladesh, Ka-66/1, Kuril, Kuratoli Rd, Dhaka 1229, Bangladesh
}

Article history

Received: 03-03-2018

Revised: 19-04-2018

Accepted: 28-04-2018

Corresponding Author:

Md. Faruque Hossain

American International

University-Bangladesh, Ka-

66/1, Kuril, Kuratoli Rd,

Dhaka 1229, Bangladesh

Email: mfhossain@aiub.edu

hossainfaruque@hotmail.com

\begin{abstract}
A study was conducted to determine the organic carbon fractions in the vertical sections of a benchmark wetland soil of Bangladesh (Arial Beel) and their dynamics that directly affect the biogeochemistry of soil, water and plant biomass ecosystem. Two distinctive soil series viz. Sara and Arial are characterized such as $\mathrm{pH}$, moisture content, textural class, CEC, organic carbon (SOC), bulk density and total organic matter etc. Different extraction methods were used for the fractionation of dissolved organic carbon such as watersoluble Fraction (WSC), hot water extractable fraction $\left(\mathrm{HWC} ; 80^{\circ} \mathrm{C}\right.$ ), labile fraction $\left(\mathrm{CaCl}_{2}-\right.$ extractable; $\left.\mathrm{LF}\right)$, moderately labile fraction (Pyrophosphate-extractable; MLF), polyaromatic fraction (toluene + methanol extractable), Microbial Biomass C Fraction (MBF) and the remaining Resistant Fraction (RF). The total organic carbon content ranges from 0.72 to $1.95 \%$; surface horizons had higher $\mathrm{C}$ than underneath horizons and prolonged inundation increased the $\mathrm{C}$ content mostly. Higher CEC of the soils had a positive correlation to HWC, MBC and RF. The DOC content particularly MLF was found higher in surface and substratum than subsurface horizons in most of the soils. The HWC and ML fraction had highly significant $(p<0.01)$ effect to increase the MBC. Resistant Fraction (RF) was the most prominent SOC fraction of the soils. The substratum of all the Arial soils had a significant amount of organic C storage $(>1 \%)$ which is relatively resistant to further degradation and might be considered as sequestered C. Short inundated period and scope of winter Robi crops might have caused Sara soil to have relatively lower organic $\mathrm{C}$ and RF than Arial. Moreover, the amount of DOC fractions in Sara series was lower and that decreased with depth but in Arial series, fractions varied within the profile.
\end{abstract}

Keywords: Organic Carbon, Fractionation, Arial Beel, Wetland Soils, Bangladesh

\section{Introduction}

Organic carbon storage in soils is a major ecosystem service, resulting from a range of natural biogeochemical processes. Intervention by human to these natural processes can lead to both carbon loss and enhanced storage. Organic carbon is one of the major factors that regulate the physical, chemical and biological properties of soil. It improves soil quality by retaining soil water and nutrients, resulting in greater productivity of plants and enhancing environmental settings. It also improves soil structure and reduces erosion, leading to improved surface and groundwater quality and finally ensures food security while decreasing negative impacts to ecosystems (Gregorich et al., 2003; Hossain et al., 2007; 2014; 2015).

Since the beginnings of recorded history, societies have understood that human activities can deplete soil productivity and the ability to produce food (Mcneill and Winiwarter, 2004). Destruction of soil carbon stocks can have large-scale impacts on whole 
ecosystems as well as can cause a substantial change in the earth's climate.

Moreover, it is estimated that $20-30 \%$ of the earth's soil carbon pool of 2,500 $\mathrm{Pg}$ (Lal, 2008) is stored in wetlands (Bridgham et al., 2006), though only about 5$8 \%$ of the terrestrial land surface are comprised of wetlands (Mitsch and Gosselink, 2000). Furthermore, scientists estimated that the world's wetlands may currently be net carbon sinks of about $830 \mathrm{Tg} /$ year, most of that carbon retention occurs in tropical and subtropical wetlands (Hossain et al., 2007; Mitsch et al., 2013). Tropical countries like Bangladesh has a vast area of wetlands including rivers and streams, haors, baors, beels, freshwater lakes and marshes and estuarine systems with enormous mangrove swamps. Periodic inundation, shallow to deep during wet monsoon etc. are the key characteristics of the wetlands here. Destruction of these wetlands that hold a significant amount of the carbon would contribute to raise atmospheric carbon dioxide $\left(\mathrm{CO}_{2}\right)$ while reducing the SOC levels. This can affect infiltration of rainfall and flood mitigation; can cause increased erosion and nutrient leaching from soils, which would lead to eutrophication and resultant algal blooms within inland aquatic and Ganges ecosystems. Therefore, a proper understanding of SOC fractions and their dynamics is essential to manage these carbon-rich wetland soils.

Soil organic carbon storage is a diversified system in terms of different fractions, alteration process, dynamic movement through the horizons and storage condition. Fractionation mainly includes physical, chemical and biological fractionations. These fractions have varying and distinct properties that affect the soil biogeochemical processes. Chemical fractionation is to separate the organic carbon into various components based on the solubility, hydrolizability and chemical reactivity of organic carbon in a variety of extracting agents. The SOC also exists as four discrete fractions which differ widely in their size, composition and turnover times in the soil, which are: Dissolved organic carbon, particulate organic $\mathrm{C}$, humus and resistant organic $\mathrm{C}$.

Dissolved Organic Carbon (DOC) in terrestrial and aquatic ecosystems varies both in time and space (Sedell and Dahm, 1990) that plays an important role in the biogeochemistry of carbon, nitrogen and phosphorus, in pedogenesis and solubility control of $\mathrm{Al}$ in soils and surface waters and in the transport of pollutants in soils (Kalbitz et al., 2000; Tipping and Hurley, 1988). Moreover, the labile carbon fraction poses a major threat to the acceleration of the greenhouse effect when released to the atmosphere (Mitsch et al., 2013). Monitoring the characteristics and dynamics of Dissolved Organic Carbon (DOC) in soil has been a great indicator of soils quality and the changed land use. However, it has merely been used as a soil quality indicator in detailed soil evaluation programs (Filep et al., 2008). Under different farmland management practices, the chemical composition and pool capacity of soil organic carbon fractions will have different variations, giving different effects on soil quality (Zhang et al., 2011). Moreover, DOC is a complex mixture of numerous solutes including fulvic, humic and hydrophilic acids (Thurman, 1985), each with their own chemical characteristics and reactivity. Fractionation of these compounds is a step toward a better understanding of their functions. However, there is some gap in information about soil organic carbon fractions in wetland soils and their management, specially the wetlands surrounded by agroecosystems. Lack of knowledge on the dynamics of the labile fractions of SOC in wetlands makes it more difficult to standardize a plan or policy to set the management priorities. To identify the qualitative or quantitative relationships between SOC components, nutrient availability, microbial composition and $\mathrm{C}$ deposition, emphasize were given to understand the movement of carbon fractions in a wetland ecosystem of Arial beel. Therefore, the objective of the study was to evaluate physicochemical properties of soil in relation to SOC and fractionation of SOC in different vertical soil sections and their biogeochemical significance in soil fertility and carbon fluxes.

\section{Materials and Methods}

Arial beel was chosen as the site for the study which is one of the major and typical wetlands of Bangladesh. As an agro-ecological zone situated in almost at the middle of the country (AEZ-15) (UNDP-FAO, 1988) and part of bio-ecological zone 4b (IUCN, 1993), the Arial beel has a great ecological, commercial and socio-economic importance. The upper part of Arial beel is Sara soil series and the lower part has Arial. Arial beel is a large depression between the Ganges and Dhaleswari rivers south of Dhaka. The total area of the beel is about 14436 ha. It lies approximately between $23^{\circ} 32^{\prime} \mathrm{N}$ to $23^{\circ} 71^{\prime} \mathrm{N}$ latitudes and $90^{\circ} 10^{\prime} \mathrm{E}$ to $90^{\circ} 37^{\prime} \mathrm{E}$ longitudes. The Arial beel belongs to Dhaka and Munshigonj Districts and located at four Upazillas namely Dohar, Nawabgonj (Fig. 1).

Soil samples were collected from top $1 \mathrm{~m}$ depth; because, SOC in the top $1 \mathrm{~m}$ of soil comprises about $3 / 4$ of the earth's terrestrial carbon (Tarnocai and Smith, 2000; Lal, 2008; Hossain et al., 2007; 2015). Composite soil samples were collected from required depths by opening at least three pits for each soil as suggested by the Soil Survey Staff of the USDA (2017). The soil samples were collected from three different depths viz. $0-15,15-40$ and $40-100 \mathrm{~cm}$ from different profiles. The first soil sample was from Sara series and another three 
were Arial series. Sara soil was collected in field moisture condition whereas Arial soils were in wet condition and inundation depth increased with Arial 1 to Arial 3, respectively. Sara soil usually remains under water for about four to six months and Robi (winter) crops are mainly cultivated, whereas Arial 3 remains under water for about 9-10 months and Boro rice in cultivated only. After collection, soil samples were placed in separate polythene bags, labeled and brought to the laboratory for analyzing different parameters. Core samples were collected for determination of bulk density from each location and depth.

The collected composite soil samples were prepared as required following the standard procedure. Moisture content of the air-dry soil, bulk density, Cation Exchange Capacity (CEC) and particle size were analyzed following the standard procedures (Black, 1965). The textural classes were determined by Marshall's triangular co-ordinates (USDA, 1951). Soil $\mathrm{pH}$ was measured electrochemically and the total organic carbon content was determined by wet oxidation method of Walkely and Black (Jackson, 1973). Soil organic carbon content was also determined by dry combustion method using LECO carbon analyzer. The results obtained from the dry combustion method were used for the description of the analysis. Organic matter content of the soil was determined by multiplying the percent value of organic carbon by conventional Van Bemmelen's factor of 1.724 (Piper, 1950).

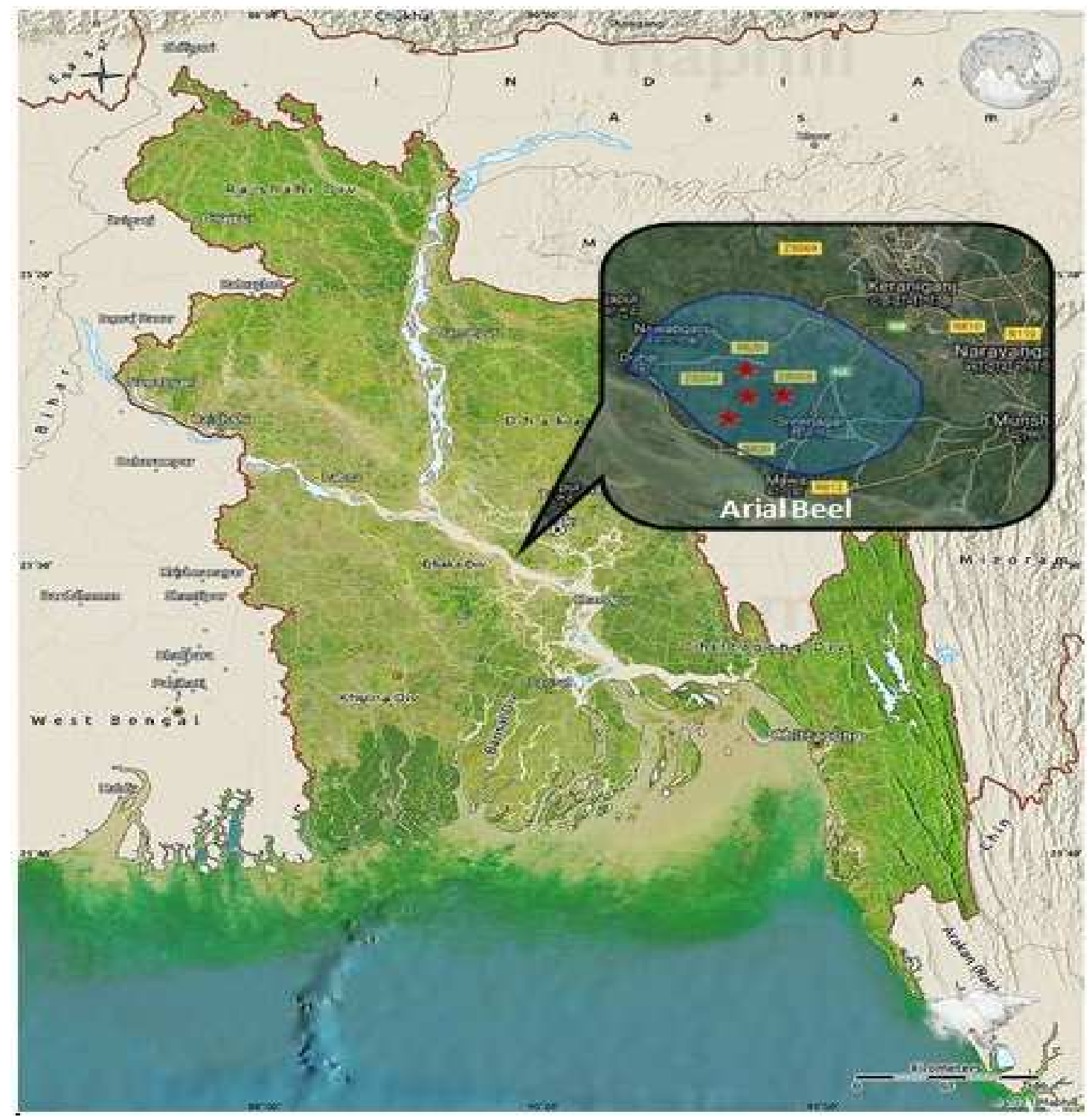

Fig. 1: Sampling location (Arial Beel, Munshigonj, Bangladesh) 


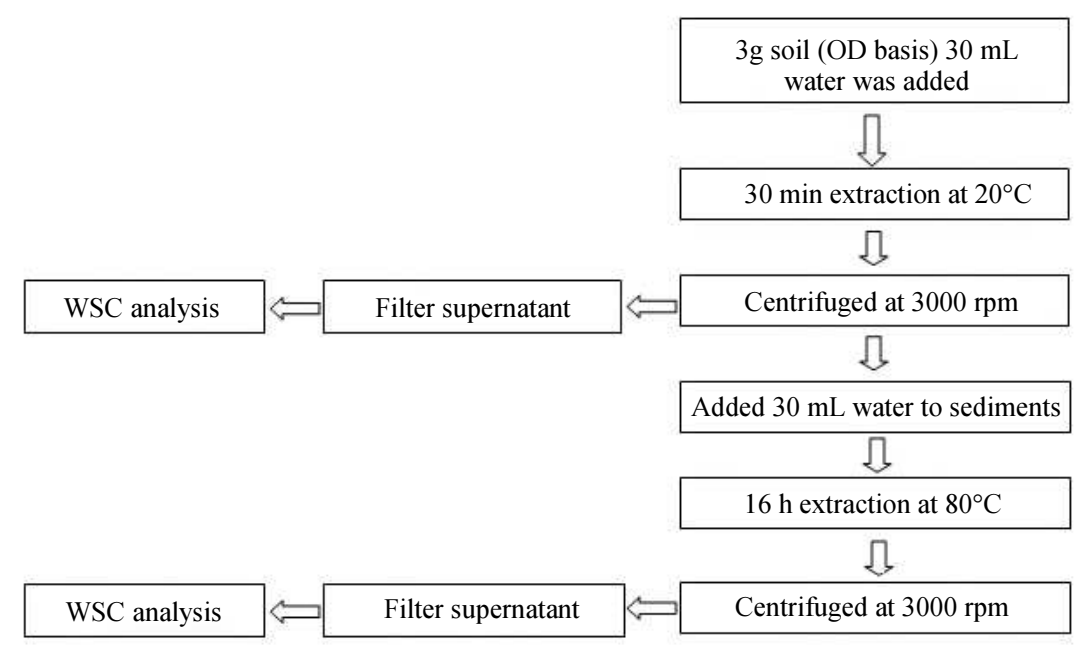

Fig. 2: Schematic diagram of the procedure for extracting water-soluble (WSC) and Hot-Water extractable C (HWC)

Table 1: Extraction methods for fractionation of SOC

\begin{tabular}{|c|c|c|c|c|c|}
\hline Fractions & Extract Solution & Soils (g) & Solution (ml) & Conditions & References \\
\hline Hot water extractable C & Distilled water & 3 & 30 & $\begin{array}{l}30 \mathrm{~min} \text { extraction at } \\
20^{\circ} \mathrm{C} \text { and } 20 \mathrm{~min} \\
\text { rotation at } 3000 \mathrm{rpm}\end{array}$ & Ghani et al. (2003) \\
\hline Water-soluble C & Distilled water & 3 & 30 & $\begin{array}{l}16 \mathrm{~h} \text { ' extraction at } \\
80^{\circ} \mathrm{C} \text { and } 20 \mathrm{~min} \\
\text { rotation at } 3000 \mathrm{rpm}\end{array}$ & Ghani et al. (2003) \\
\hline Labile $\mathrm{C}$ fraction & $10 \mathrm{mM} \mathrm{CaCl}_{2}$ & 2 & 30 & $\begin{array}{l}24 \mathrm{~h}^{\prime} \text { end-over-end } \\
\text { rotation }(40 \mathrm{rpm}) \text { at } 25^{\circ} \mathrm{C}\end{array}$ & Erich et al. (2011) \\
\hline Moderately labile & $125 \mathrm{mM} \mathrm{Na}_{4} \mathrm{P}_{2} \mathrm{O}_{7}(\mathrm{pH} \mathrm{5})$ & 2 & 30 & $\begin{array}{l}24 \mathrm{~h} \text { ' end-over-end } \\
\text { rotation }(40 \mathrm{rpm}) \text { at } 25^{\circ} \mathrm{C}\end{array}$ & Erich et al. (2011) \\
\hline Polyaromatic DOC & $\begin{array}{l}\text { Toluene }+ \text { methanol } \\
\mathrm{C} \text { fraction }(1: 6 \mathrm{v} / \mathrm{v})\end{array}$ & 2 & 30 & $\begin{array}{l}24 \mathrm{~h} \text { ' end-over-end } \\
\text { rotation }(40 \mathrm{rpm}) \text { at } 25^{\circ} \mathrm{C}\end{array}$ & $\begin{array}{l}\text { Jonker and } \\
\text { Kaelmans (2002) }\end{array}$ \\
\hline Microbial biomass $\mathrm{C}$ & $0.5 \mathrm{M} \mathrm{K}_{2} \mathrm{SO}_{4}$ & 20 & 100 & $\begin{array}{l}1 \mathrm{~h} \text { shake, sterilization, } \\
\text { and extraction }\end{array}$ & Ghani et al. (2003) \\
\hline
\end{tabular}

The extraction methods have been enlisted in the Table 1. The Hot-Water extractable Carbon (HWC) was determined on fresh field samples by a modified method (Ghani et al., 2003). The extraction of HWC was conducted in two simple steps (Fig. 2). The first step involved separation of Water-Soluble C (WSC) from the soils that may have come from recent liming of the soil or from animal excreta and soluble plant residues. The second step involved extraction of labile components of soil carbon at $80^{\circ} \mathrm{C}$ for $16 \mathrm{~h}$. This was subsequently referred to as hotwater extractable carbon. All the supernatant was filtered through $0.45 \mathrm{~mm}$ cellulose nitrate membrane filter into separate vials. Total carbon (inorganic and organic $\mathrm{C}$ ) in both the first and second vials was determined by a Shimadzu Total Organic Carbon (TOC) analyzer.

Volumes of $40 \mathrm{~mL}$ of the extracts were injected in the detection chamber for the analysis of total C (3 times). This method gave $98 \%$ reproducibility of results from the same extracts (unpublished data). The HWC was the organic fraction of the total extractable $\mathrm{C}$ that was determined by subtracting the inorganic $\mathrm{C}$ values from the total hot-water extractable $\mathrm{C}$. The inorganic $\mathrm{C}$ content in the extracts were generally less than $4 \%$ of the total hot-water extractable $\mathrm{C}$.

All filtered extracts were analyzed for total organic $\mathrm{C}$ using TOC analyzer. Field moist soil samples were analyzed for microbial biomass-C. Duplicate soilsamples ( $5 \mathrm{~g}$ dry weight) are fumigated with chloroform for $24 \mathrm{~h}$ and then extracted with $0.5 \mathrm{M} \mathrm{K}_{2} \mathrm{SO}_{4}$ for $2 \mathrm{~h}$ on an end-over-end shaker. It was then calculated as the difference between the values for fumigated and nonfumigated soils (Ghani et al., 2003). The data are statistically analyzed using Microsoft Excel and Stata software version 14 .

\section{Results and Discussion}

As wetland soils remain under water for more than nine months or so, the submergence directly affects the $\mathrm{pH}$ change due to continuous reduction. At first, $\mathrm{pH}$ falls due to the absence of oxygen $\left(\mathrm{O}_{2}\right)$ and availability of carbon-di-oxide $\left(\mathrm{CO}_{2}\right)$ that forms 
carbonic acid, then ultimately due to the conversion of that $\mathrm{CO}_{2}$ to methane $\left(\mathrm{CH}_{4}\right), \mathrm{pH}$ rises with time. Wetland soils are more neutral or sometimes acidic. The $\mathrm{pH}$ of the wetland soil samples was slightly acidic to neutral and ranges from 6.15 to 7.20 but no significant variations were observed among the vertical sections of the studied soils (Table 2).

The values of moisture content of the wetland soil samples were found to lie in the ranges from 46.42 to $54.32 \%$ (Table 2). Bulk Density (BD) and organic C are significantly co-related to each other. Higher bulk density indicates lower organic $\mathrm{C}$ content. Clay and claysized particles are washed out or leached out from surface to subsurface or substratum; left upper layer becomes loose due to the absence of small sized particles. BD of surface soils found lower than subsurface or substratum soils in this study, ranging from 1.30 to $1.42 \mathrm{~g} / \mathrm{cm}^{3}$. Generally, SOC content is high in surface layer in upland soils but SOC measurement in wetlands is very sensitive because of the development of anaerobic conditions in wetlands profile, which attributes to the production of methane $\left(\mathrm{CH}_{4}\right)$ and the decomposed plant material results in the production of dissolved organic carbon, a mixture of complex organic molecule (Hossain et al., 2015). Though the total soil organic carbon was found lower in the soils of Arial beel compared to other wetlands around the world, it is substantially greater than most of the Bangladeshi soils (Bhuiya, 1987). The highest $3.36 \%$ of organic matter was contained in the surface horizon of the Arial 2 soil.

Assessment of soil organic matter is a valuable step towards identifying the overall quality of a soil. A substantial amount of organic matter was observed in the entire area of the Arial beel. The values of OM range from 1.90 to $3.36 \%$ (Table 2), which is higher than most mineral soils of Bangladesh. This high content of $\mathrm{OM}$ is representative to the high productivity of this wetland. Due to continuous submergence, the OM remains comparatively high because of the absence of $\mathrm{OM}$ decomposing aerobic micro-organisms. A significant amount $(2.33 \%)$ of organic matter was found in the substratum of Arial 2, which might be due to the migration of dissolved organic matters from the overlying layers.

Cation exchange capacity is one of the most important characteristics of a productive soil. The value of CEC ranges from 10.16 to $20.56 \mathrm{meq} / 100 \mathrm{~g}$ (Table 2), which is higher than most upland soils. The high nutrient holding capacity of the seasonally flooded soils depends primarily on high CEC that controls the adsorption capacity of nutrient ions (Akter et al., 2011). Due to having clay texture and high content of OM the CEC of these wetland soils are very high. High CEC of the Arial 2 soil might be directly correlated to its high SOC content.

Fine textured soils increase from surface to subsurface for each profile due to clay accumulation by elevation in bottom layers. Clay soils are one of the most productive soils of the world as they can retain more water and OM, which can ultimately hold more nutrients. In Sara series, textural class of surface and subsurface is silt loam but substratum is silty clay. The textural class of all Arial beel soils is clay. The best soils for agricultural crops specifically for the rice crops are the silty clay to clay loam which showed relevancy with the above textural class.

Recalcitrant organic carbon or the resistant fraction can take centuries to decompose and is mostly unavailable to microbes. Thus, having a good amount of RF stored in soils is important for the $\mathrm{C}$ sequestration. A substantial quantity of carbon is associated with the resistant fraction, the value ranges from 5468 to 17055 $\mu \mathrm{g} \mathrm{g}^{-1}$ which is about 75 to $88 \%$ of total SOC. Resistant fraction shows meaningful relationship with CEC $(\mathrm{r}=$ $\left.0.743^{* *}\right)$ and $\operatorname{SOC}\left(\mathrm{r}=0.997^{* *}\right)$ but no significant relationships with $\mathrm{pH}$, clay and $\mathrm{BD}$ (Table 3 ). The study found trace amount of Polyaromatic Dissolved Organic $\mathrm{C}$ (PDOC). However, the distributions of SOC fractions in the samples are presented in Fig. 3.

Table 2: Some physical, chemical and physicochemical properties of Arial beel soils

\begin{tabular}{|c|c|c|c|c|c|c|c|c|c|c|}
\hline Soils & Layers & $\mathrm{pH}$ & $\begin{array}{l}\text { Moisture } \\
\%\end{array}$ & $\begin{array}{l}\mathrm{BD} \\
\left(\mathrm{g} \mathrm{cm}^{-3}\right)\end{array}$ & $\begin{array}{l}\text { SOC (\% } \\
\text { dry weight) }\end{array}$ & $\begin{array}{l}\text { OM (\% } \\
\text { dry weight) }\end{array}$ & $\begin{array}{l}\text { CEC meq } \\
100 \mathrm{~g}^{-1}\end{array}$ & Texture & PDOC & $\mathrm{RF}$ \\
\hline \multirow[t]{3}{*}{ Sara } & Surface & $7.20 \pm 0.11$ & $38.98 \pm 0.72$ & $1.38 \pm 0.121$ & $1.10 \pm 0.07$ & $1.89 \pm 0.12$ & $12.07 \pm 0.26$ & Silt loam & Trace & 8905 \\
\hline & Subsurface & $7.12 \pm 0.16$ & $37.65 \pm 0.32$ & $1.41 \pm 0.16$ & $0.76 \pm 0.06$ & $1.31 \pm 0.03$ & $10.19 \pm 1.10$ & Silt loam & Trace & 5863 \\
\hline & Substratum & $6.55 \pm 0.13$ & $42.76 \pm 0.54$ & $1.42 \pm 0.09$ & $0.72 \pm 0.07$ & $1.21 \pm 0.05$ & $10.16 \pm 0.50$ & Silty clay & Trace & 5468 \\
\hline \multirow[t]{3}{*}{ Arial 1} & Surface & $6.64 \pm 0.07$ & $54.32 \pm 0.86$ & $1.32 \pm 0.07$ & $1.67 \pm 0.12$ & $2.88 \pm 0.13$ & $15.20 \pm 0.63$ & Clay & Trace & 14400 \\
\hline & Subsurface & $6.44 \pm 0.03$ & $52.41 \pm 1.24$ & $1.35 \pm 0.08$ & $1.12 \pm 0.13$ & $1.93 \pm 0.06$ & $10.67 \pm 0.47$ & Clay & Trace & 9780 \\
\hline & Substratum & $6.69 \pm 0.06$ & $51.24 \pm 1.10$ & $1.36 \pm 0.12$ & $1.15 \pm 0.14$ & $1.98 \pm 0.04$ & $12.23 \pm 0.08$ & Clay & Trace & 9409 \\
\hline \multirow[t]{3}{*}{ Arial 2} & Surface & $6.26 \pm 0.31$ & $52.22 \pm 0.47$ & $1.30 \pm 0.13$ & $1.95 \pm 0.08$ & $3.36 \pm 0.09$ & $20.56 \pm 0.87$ & Clay & Trace & 17055 \\
\hline & Subsurface & $6.49 \pm 0.07$ & $49.81 \pm 0.59$ & $1.35 \pm 0.21$ & $1.12 \pm 0.15$ & $1.90 \pm 0.13$ & $15.43 \pm 1.13$ & Clay & Trace & 9225 \\
\hline & Substratum & $6.15 \pm 0.08$ & $51.98 \pm 0.79$ & $1.32 \pm 0.24$ & $1.35 \pm 0.11$ & $2.33 \pm 0.07$ & $19.89 \pm 0.75$ & Clay & Trace & 11400 \\
\hline \multirow[t]{3}{*}{ Arial 3} & Surface & $6.72 \pm 0.04$ & $50.91 \pm 0.54$ & $1.35 \pm 0.18$ & $1.01 \pm 0.09$ & $2.01 \pm 0.02$ & $16.44 \pm 1.30$ & Clay & Trace & 7597 \\
\hline & Subsurface & $6.36 \pm 0.02$ & $48.59 \pm 0.48$ & $1.38 \pm 0.11$ & $1.67 \pm 0.12$ & $2.88 \pm 0.11$ & $18.91 \pm 0.34$ & Clay & Trace & 14120 \\
\hline & Substratum & $7.02 \pm 0.04$ & $46.42 \pm 1.13$ & $1.40 \pm 0.19$ & $1.12 \pm 0.14$ & $1.94 \pm 0.03$ & $15.65 \pm 0.48$ & Clay & Trace & 9550 \\
\hline
\end{tabular}

$\mathrm{BD}=$ Bulk density, $\mathrm{SOC}=$ Soil organic carbon, $\mathrm{OM}=$ Organic matter, $\mathrm{CEC}=$ Cation exchange capacity, $\mathrm{PDOC}=\mathrm{Polyaromatic}$ dissolved organic $\mathrm{C}$ and $\mathrm{RF}=$ Resistant fraction 
Monera Akter Eva et al. / American Journal of Environmental Sciences 2018, 14 (2): 86.94 DOI: 10.3844/ajessp.2018.86.94

Table 3: Correlation coefficient of individual SOC fractions and some soil properties

\begin{tabular}{|c|c|c|c|c|c|}
\hline \multirow[b]{2}{*}{ SOC fractions $\left(\mu \mathrm{g} \mathrm{g}^{-1}\right)$} & \multicolumn{5}{|c|}{ Soil properties } \\
\hline & $\mathrm{pH}$ & Clay\% & $\mathrm{CEC} \mathrm{me} / 100 \mathrm{~g}$ & $\mathrm{BDg} \mathrm{cm}^{-3}$ & $\operatorname{SOC}\left(\mu g_{g}^{-1}\right)$ \\
\hline HWC & -0.159 & 0.223 & $0.774 * *$ & -0.136 & $0.619^{*}$ \\
\hline WSC & -0.255 & 0.095 & 0.047 & 0.042 & $0.656^{*}$ \\
\hline $\mathrm{LF}$ & 0.115 & -0.199 & 0.485 & 0.542 & $0.728^{* *}$ \\
\hline MLF & -0.109 & -0.092 & 0.517 & -0.380 & 0.512 \\
\hline $\mathrm{MBC}$ & -0.060 & 0.139 & $0.684 *$ & -0.219 & $0.582 *$ \\
\hline $\mathrm{RF}$ & -0.145 & -0.139 & $0.743 * *$ & 0.428 & $0.997 * *$ \\
\hline
\end{tabular}

Note: *indicates 0.05 and $* *$ indicates $0.01 \%$ level of significance

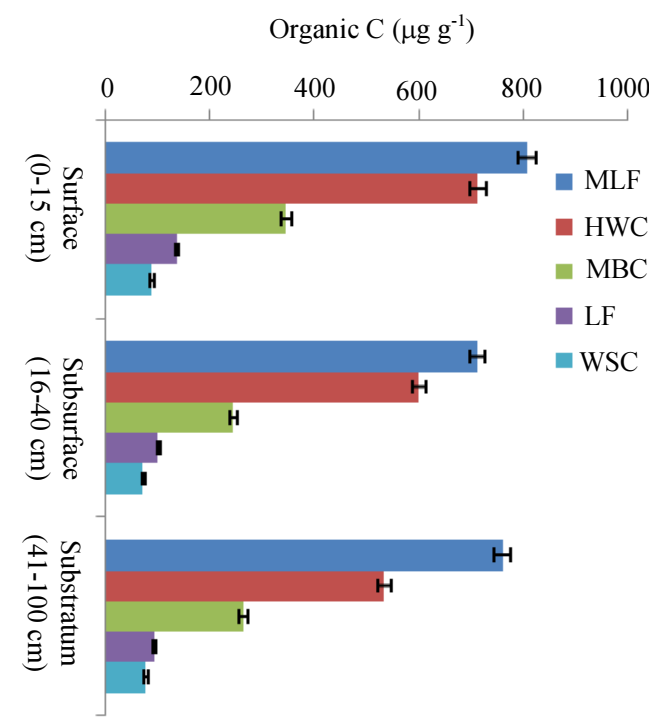

(a)

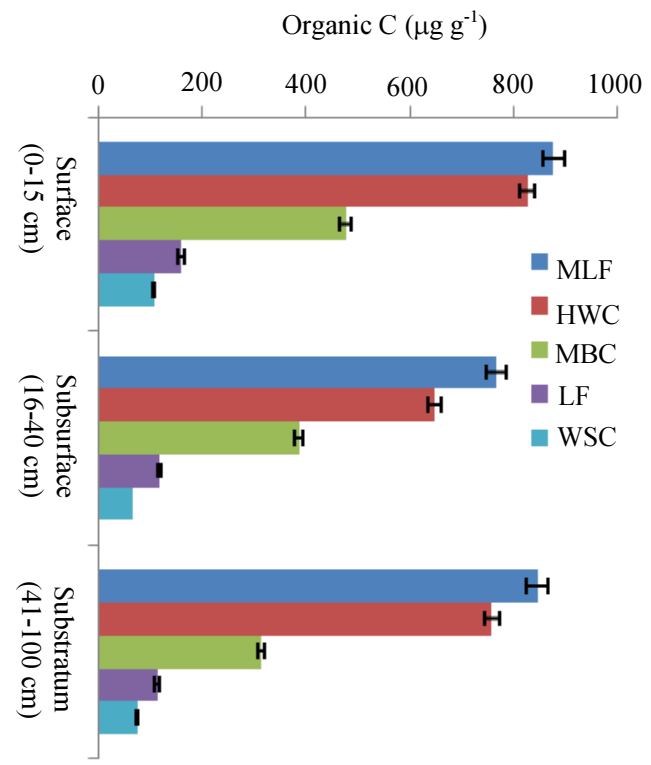

(c)

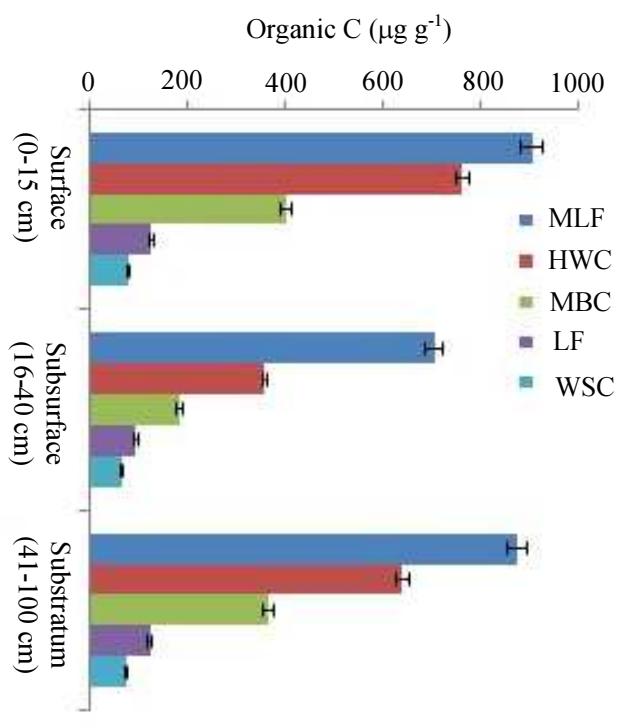

(b)

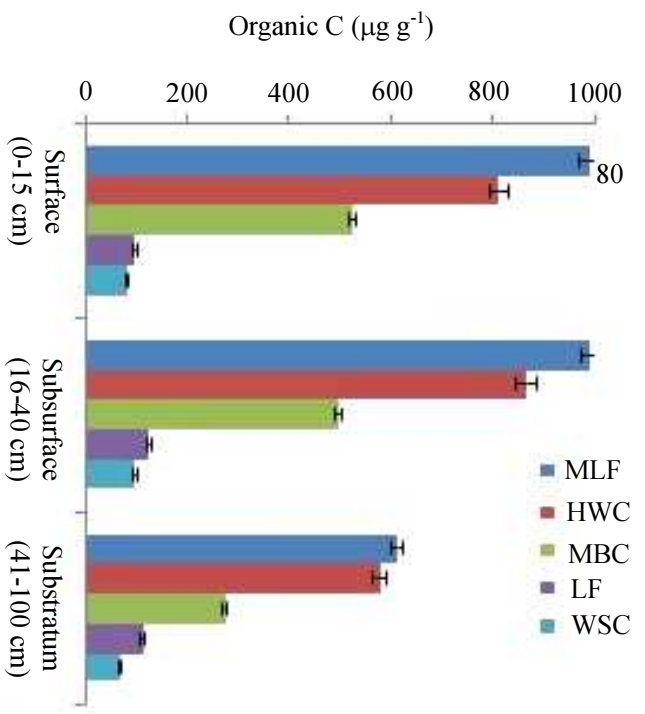

(d)

Fig. 3: Fractionation of soil organic $\mathrm{C}\left(\mu \mathrm{g} \mathrm{g}^{-1}\right)$ in the studied soils; (a) Sara; (b) Arial 1; (c) Arial 2; (d) Arial 3; Note: MLF= moderately labile fraction $\mathrm{HWC}=$ Hot Water-extractable $\mathrm{C}, \mathrm{MBC}=$ Microbial Biomass Carbon, $\mathrm{LF}=$ Labile Fraction and WSC $=$ Water-Soluble C 
There have been suggestions that the WSC being part of the highly labile pool of $\mathrm{C}$, may also be sensitive to perturbation and stress in the soil-plant ecosystem (Ghani et al., 2003) and therefore, could be used as a sensitive indicator of soil quality. However, WSC is usually considerably smaller than other labile pools. Values are ranges from 63 to $106 \mu \mathrm{g} \mathrm{C} \mathrm{g}^{-1}$ in the examined soils which are about $1 \%$ of total SOC. Percent value of WSC is quite similar to the findings of 1 to $1.25 \%$ WSC in the plots of the Maine potato ecosystem (Erich et al., 2011). Bu et al. (2011) found 0.2 to $0.5 \%$ WSC in air-dry surface soil and 0.1 to $0.4 \%$ WSC in oven dry A, B and C horizons (Ruqin et al., 2013). Using field-moist soils generally yields somewhat less WSC (e.g., 0.01 to $0.3 \%$, Kim et al., 2012).

The amount of WSC varies from soil to soil primarily depending on soil C content. Also, WSC being a highly labile pool of carbon had a greater variability than the HWC (Ghani et al., 2003). Soil WSC acts as a potential nutrient source to plants and soil microorganisms, facilitates transport of inorganic and organic contaminants, regulates the production of greenhouse gases such as $\mathrm{CH}_{4}$ and overall degrades water quality (Zsolnay, 2003).

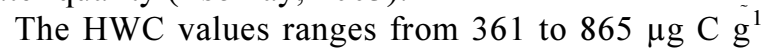
soil or $3-8 \%$ of total SOC. Considerably higher amounts of $\mathrm{C}$ found in the HWC because it would have extracted not only the microbial biomass- $\mathrm{C}$ but also root exudates, soluble carbohydrates and amino acids. The $\mathrm{C}$ bound to soil enzymes would also be extracted because most of the soil enzymes in these soils would be denatured at $80^{\circ} \mathrm{C}$. Most of these components of SOM are regarded as labile in nature (Ghani et al., 2003). The relationships between HWC and SOC and CEC are positively significant (Table 3 ). The amount of HWC increases with increase in SOC and $\mathrm{CEC}$, whereas no relationship is observed between HWC and $\mathrm{pH}$ or clay, which indicates HWC might not dependent on any of these properties.

$\mathrm{CaCl}_{2}$ extractable Labile $\mathrm{C}$ fraction ranges from 93 to $159 \mu \mathrm{g} \mathrm{C} \mathrm{g}^{-1}$ in the soils, which is almost $1 \%$ of total SOC. This amount of labile $\mathrm{C}$ fraction was almost the same for all studied soils. However, a group of scientists reported slightly higher range (1 to $1.50 \% \mathrm{LF}$ of total SOC) in some wetland soils (Erich et al., 2011). Labile
$\mathrm{C}$ fraction is mainly consisting of decomposing plant and animal residues. This fraction breaks down relatively quickly and is an active source of nutrients. Labile carbon is the major food source of soil microbes.

Pyrophosphate extractable organic carbon fraction (moderately labile fraction-MLF) ranges from 613 to $991 \mu \mathrm{g} \mathrm{C} \mathrm{g}^{-1}$ soil or 4 to $10 \%$ of total SOC. Pyrophosphate extracted much greater amount of $\mathrm{C}$ than water or $\mathrm{CaCl}_{2}$. There was no significant effect of depth on the amount of $\mathrm{C}$ extracted by pyrophosphate, suggesting that mineral surface area or surface functional groups determine the amount of pyrophosphate-extractable $\mathrm{C}$ in soil (Erich et al., 2011). This fraction consists of molecules soluble through a ligand exchange reaction which removes Fe and Al cations. This fraction likely represents materials that can chemically sorb to the clay surface and protected from decomposition, which implies this fraction isn't easily available to microbes for decomposition.

Microbial biomass $\mathrm{C}$ values ranges from 186 to $524 \mu \mathrm{g} \mathrm{C} \mathrm{g} \mathrm{g}^{-1}$ in soil samples and 2 to $5 \%$ of total soil organic $\mathrm{C}$. Generally, microbial biomass $\mathrm{C}$ ranges from 1 to $5 \%$ of total SOC but not exceed over $8 \%$ (Erich et al., 2011). This fraction is a measure of the carbon contained within the living component of soil organic matter. Table 3 demonstrates that the relationships of $\mathrm{MBC}$ with SOC and $\mathrm{CEC}$ are positively significant.

All the data collected from various fractions are pooled together to examine the correlations among these fractions. Correlation between HWC and WSC, LF, MLF and MBC are positive and significant (Table 4). Several scientists also reported a strong positive correlation between $\mathrm{HWC}$ and microbial biomass $\mathrm{C}$ (Erich et al., 2011). The amounts of HWC extracted from soils are much higher than extracted as microbial biomass C. The relationships of WEC with MLF, $\mathrm{MBC}$ and RF are positively significant at 0.05 level and LF with RF and MLF with MBC are positively significant at $0.01 \%$ levels (Table 4 ). The variation in Sara and Kalma soil's SOC fractions might be due to difference in flooding and soil management condition (Wilson et al., 2011).

Table 4: Relationship among different fractions of SOC in soils

\begin{tabular}{llllll}
\hline Fractions of SOC $\left(\mu \mathrm{g} \mathrm{g}^{-1}\right)$ & HWC & WSC & LF & MLF & MBC \\
\hline HWC & & & & & \\
WSC & $0.698^{*}$ & & & & \\
LF & $0.582^{*}$ & 0.565 & & & \\
MLF & $0.794^{* *}$ & $0.643^{*}$ & 0.329 & $0.854^{* *}$ & 0.518 \\
MBC & $0.887^{* *}$ & $0.666^{*}$ & 0.483 & 0.448 & $0.717^{* *}$ \\
RF & 0.558 & $0.620^{*}$ & & &
\end{tabular}

Note: *indicates 0.05 and $* * 0.01$ level of significance 


\section{Conclusion}

Wetlands receive a significant amount of dissolved organic carbon in any fluvial ecosystem and acting as a reservoir makes a direct link between the soil-water and atmospheric carbon. However, several numbers of factors like temperature, rainfall, land-use, nitrogen and $\mathrm{CO}_{2}$ enrichment etc. are causing to increase Dissolved Organic Carbon (DOC) in upland water bodies like wetlands. These fraction of organic carbon and associated nutrients have been blessings for wetland agriculture particularly which are seasonally inundated. However, the uncertainty of the movements of these labile $\mathrm{C}$ fractions and their decomposition might cause a threat to the ecosystem services of a wetland. Therefore, proper quantification of these fractions in water and soil horizons and the acting factors like seasonal variation, inundation depth, land management, cropping system might help to understand the dynamics of organic $\mathrm{C}$ in the wetland system. The substratum of the studied soils had a significant amount of $\mathrm{C}$ stored which implies the $\mathrm{C}$ sequestration service of tropical wetlands. Short inundation period and intensive agriculture of Sara soils might have caused the reduction of organic $\mathrm{C}$ storage. Therefore, it is essential to evaluate the factors that are causing the degradation of these wetlands and their Cstoring capacity. Furthermore, detailed and comprehensive studies are needed for better understanding and integrated management of SOC in the wetland soils of Bangladesh.

\section{Acknowledgment}

The authors would like to thank Dept. of Soil, Water and Environment, University of Dhaka and Soil Resources Development Institute (SRDI), Government of Bangladesh for their lab facilities. The authors would also express sincere gratitude to Md Delwar Hossain Molla of SRDI for his immense support in the sampling process.

\section{Author's Contributions}

Monera Akter Eva: Sampling, Laboratory experiments, Statistical design, Initial manuscript.

Mahmudul Islam Piash: Sampling, Interpretation of data, Manuscript writing, Graphical presentation and revision.

Md. Faruque Hossain: Research plan, Supervision, Data interpretation, Manuscript review, preparation for publication and revision.

Zakia Parveen: Research plan, Supervision and manuscript review.

\section{Ethics}

The content of this article is original and contains unpublished materials. The corresponding author confirms that all the other authors have read and approved the manuscript and there are no ethical issues involved.

\section{References}

Akter, K.F., Z.H. Khan, M.S. Hussain and A.R. Mazumder, 2011. Physico-chemical characteristics of the seasonally flooded soils of Bangladesh and their management implications. Dhaka Univ. J. Biol. Sci., 20: 173-182. DOI: 10.3329/dujbs.v20i2.8978

Black, C.A., 1965. Methods of soil analysis. Part 2. Agron Series 9, American Society of Agronomy. Madison. Wisconsin.

Bhuiya, Z.H., 1987. Organic matter status and organic recycling in Bangladesh soils. Resources Conservat., 13: 117-124. DOI: $10.1016 / 0166-3097(87) 90055-1$

Bridgham, S.D., J.P. Megonigal, J.K. Keller, N.B. Bliss and C. Trettin, 2006. The carbon balance of North American wetlands. Wetlands, 26: 889-916.

$\mathrm{Bu}, \mathrm{X}$., J. Ding, L. Wang, X. Yu and W. Huang et al., 2011. Biodegradation and chemical characteristics of hot-water extractable organic matter from soils under four different vegetation types in the Wuyi Mountains, Southeastern China. Euro. J. Soil Biol., 48: 102-107. DOI: 10.1016/j.ejsobi.2010.11.009

Erich, M.S., A.F. Plante, J.M. Fernández, E.B. Mallory and T. Ohno, 2011. Effects of Profile depth and management on the composition of labile and total soil organic matter. Am. J. Soil Sci. Soc., 76: 408-419. DOI: $10.2136 /$ sssaj2011.0273

Evans, C.D., D.T. Monteith and D.M. Cooper, 2005. Long-term increases in surface water dissolved organic carbon: observations, possible causes and environmental impacts. Environ. Pollut., 137: 55-71. DOI: $10.1016 /$ j.envpol.2004.12.031

Filep, T., R. Márk and I. Kincses, 2008. Effect of soil quality on Dissolved Organic Matter (DOM) content of soils. Cereal Res. Commun., 36: 667-670.

Ghani, A., M. Dexer and K.W. Perrott, 2003. Hot-water extractable carbon in soils: A sensitive measurement for determining impacts of fertilisation, grazing and cultivation. Soil Biol. Biochem., 35: 1231-1243. DOI: $10.1016 / \mathrm{S} 0038-0717(03) 00186-\mathrm{X}$

Gregorich, E., M.R. Carter, D.A. Angers, C.M. Monreal and B.H. Ellert, 2003. Towards a minimum data set to assess soil organic matter quality in agricultural soils. Can. J. Soil Sci., 74: 367-385.

Hossain, M.F., Y. Zhang, W. Chen, J. Wang and G. Pavlic, 2007. Soil organic carbon content in northern canada: A database of field measurements and its analysis. Can. J. Soil Sci., 87: 259-268. DOI: 10.4141/S06-029

Hossain, M.F., Y. Zhang and W. Chen. 2014. Uncertainty assessment of a polygon database of soil organic carbon for greenhouse gas reporting in canada's arctic and sub-arctic. Info. Process. Agric., 1: 34-41. DOI: $10.1016 /$ j.inpa.2014.04.002 
Hossain, M.F., Y. Zhang, W. Chen and M.J. Uddin. 2015. Soil carbon stock measurements and distribution over Canada's North. Res. J. Agric. Environ. Manage., 4: 112-130.

IUCN. 1993. Characteristics and dynamics of wetland soils in bangladesh. Wetland Publication, Dhaka, Bangladesh.

Jackson, M.L., 1973. Soil chemical analysis. Prentice-hall inc. Englewood Cliffs, New Jersey.

Jonker, M.T.O. and A.A. Koelmans, 2002. Extraction of polycyclic aromatic hydrocarbons from soot and sediment: $\square$ Solvent evaluation and implications for sorption mechanism. Environ. Sci. Technol., 46: 4107-4113. DOI: 10.1021/es0103290

Kalbitz, K., S. Solinger, J.H. Park, B. Michalzik and E. Matzner, 2000. Controls on the dynamics of dissolved organic matter in soils: A review. Soil science, 165: 277-304.

Kim, Y.S., M.J. Yi, Y.Y. Lee, Y. Son and T. Koike, 2012. Characteristics of Soil $\mathrm{CO}_{2}$ efflux in evenaged alder compared to Korean pine plantations in central Korea. J. Forest Environ. Sci., 28: 232-241. DOI: $10.7747 /$ JFS.2012.28.4.232

Lal, R., 2008. Carbon sequestration. Philosophical Trans. R Society London B, 363: 815-830.

Mcneill, J.R. and V. Winiwarter, 2004. Breaking the sod: Humankind, history and soil. Science, 304: 1627-1629. DOI: $10.1126 /$ science. 1099893

Mitsch, W.J. and J.G. Gosselink, 2000. Wetlands. 4th Edn, Wiley, Hoboken.

Mitsch, W.J., B. Bernal, A.M. Nahlik, Ü. Mander and L. Zhang et al., 2013. Wetlands, carbon and climate change. Landscape Ecol., 28: 583-597.

Piper, G.S., 1950. Soil and Plant Analysis. Adelaide Univ. Press, Australia.

Ruqin, F., Z. Xiaoping, S. Yan, Y. Xueming and L. Aizhen, 2013. Near-infrared spectroscopic assessment of hot water extractable and oxidizable organic carbon in cultivated and uncultivated mollisols in china. Acta Agric. Scandinavica, 63: 37-45. DOI: 10.1080/09064710.2012.711353

Sedell, J.R. and C.N. Dahm, 1990. Spatial and temporal scales of dissolved organic-carbon in streams and rivers.
Tarnocai, C. and C.A.S. Smith, 1992. The formation and properties of soils in the permafrost regions of Canada. Proceedings of the 1st International Conference on Cryopedology, (ICC' 1992), Pushchino, Russia.

Thurman, E.M., 1985. Organic Geochemistry of Natural Waters. Martinus Nijhoff/Dr. W. Junk, Dordrecht, Netherlands.

Tipping, E. and Hurley, M.A., 1988. A model of solid-solution interactions in acid organic soils, based on the complexation properties of humic substances. Eur. J. Soil Sci., 39: 505-519. DOI: 10.1111/j.1365-2389.1988.tb01235.x

Wilson, J.S., D.S. Baldwin, G.N. Rees and B.P. Wilson, 2011. The effects of short-term inundation on carbon dynamics, microbial community structure and microbial activity in floodplain soil. River Res. Applic., 27: 213-225. DOI: 10.1002/rra.1352

UNDP-FAO, 1988. Land resource appraisal of Bangladesh for agricultural development. Report 2: Agroecological regions of Bangladesh.

USDA, 1951. Soil survey manual. Soil Survey Staff, Bureau of Plant Industry, Soil and Agricultural Engineering, United States Department of Agriculture, Washington.

USDA, 2017. Soil survey manual. Soil Survey Staff, Bureau of Plant Industry, Soils and Agricultural Engineering, United States Department of Agriculture, Washington. Handbook No. 18 provides the major principles and practices needed for making and using soil surveys.

Zhang, G., Z.P. Cao and C.J. Hu, 2011. Soil organic carbon fractionation methods and their applications in farmland ecosystem research: A review. Yingyong Shengtai Xuebao, 22: 1921-1930. PMID: 22007474

Zsolnay, A., 2003. Dissolved organic matter: Artefacts, definitions and functions. Geoderma, 113: 187-209. DOI: 10.1016/S0016-7061(02)00361-0 